\title{
BIOPROCESS APPLIED TO THE TREATMENT OF RESIDUAL WATERS OF COFFEE WET PROCESSING FOR THE INCORPORATION OF SELECTED YEAST STRAINS *
}

\author{
MARCIA REGINA BEUX ** \\ CARLOS ITSUO YAMAMOTO *** \\ CRISTINA MARA GUOLO WINTER **** \\ WILTON FONTES RAMOS $* * * * *$ \\ FABIANA NICOL BARBIERI ${ }^{* * * *}$ \\ JOSÉ LAURENTINO FERREIRA ***** \\ CARLOS RICARDO SOCCOL ${ }^{\star \star \star \star \star \star *}$
}

The aim of the present work was to isolate yeast strains able to degrade the degumming water originated from the wet processing of coffee, characterizing the formed metabolites. The drink prepared from the treated grains by wet processing is considered of better quality when compared with the grains treated by dry process. However, the great polluent potential of the residual water from this processing represents serious concern for the environment. The degumming water essentially presents organic contamination, with Oxygen Biochemical Demand (OBD) and Oxygen Chemical Demand (OCD) rates superior to $20.000 \mathrm{mgO}_{2} / \mathrm{L}$. Candida tropicalis, C. Iypolitica, C. guilliermondii, C. parapsilopsis, Kloeckera apiculata e Rhodotorula rubra, isolated from coffee cheeries were inoculated in flasks containing the degumming water and then submitted to constant agitation $(120 \mathrm{rpm})$ for 48 hours at $28^{\circ} \mathrm{C}$. The isolated species revealed capacity to degrade the substrate, however C.parapsilopsis showed reduction percentages of OBD and OCD rates of $50.14 \%$ e $29.81 \%$, respectivelly, showing the viability of the use of those microorganisms as biological depollutants.

KEY-WORDS: COFFEE; DEGUMMING WATER; YEAST.

* Parte do projeto de tese de Doutorado em Tecnologia de Alimentos da primeira autora.

** Doutoranda, Programa de Pós-Graduação em Tecnologia de Alimentos, Universidade Federal do Paraná (UFPR), Coordenadora da Área Biológica do Centro de Pesquisa e Processamento de Alimentos (CEPPA), Professora da Disciplina de Controle de Qualidade do Curso de Farmácia e Bioquímica, Pontifícia Universidade Católica do Paraná (PUC), Curitiba, PR (e-mail mrbeux@engquim.ufpr.br).

Doutor em Engenharia Química, Professor do Departamento de Engenharia Química, UFPR e Chefe do CEPPA.

**** Farmacêutica Industrial, Especialista em Vigilância Sanitária em Alimentos, GerenteTécnica do Laboratório de Físico-Química de Alimentos, CEPPA, Curitiba, PR.

Técnicos em Saneamento Básico e Ambiental do Laboratório de Físico-Química de Águas e Efluentes, CEPPA, Curitiba, PR.

Físico do Laboratório de Alimentos do Instituto de Tecnologia do Paraná (TECPAR), Especialista em Controle Estatístico de Qualidade, Curitiba, PR.

Orientador do Projeto de Tese de Doutorado, Pós-Doutorado em Biotecnologia, Institut Français de Recherche Scientific Pour le Devellopement en Cooperat, Orstom, França; Professor Coordenador, Curso de Engenharia de Bioprocessos e Biotecnologia, UFPR (e-mail: soccol@ ufpr.br). 


\section{INTRODUCTION}

Brazil is the largest producer of coffee, being responsible for $28 \%$ of the world production. The State of Paraná contributes with $5.8 \%$ of the total produced in the country (DEMARCHI, 2001).

Although it exists about twenty-five varieties of coffee, only two are commercially cultivated: the Arabic and the Robust. Coffea arabica produces coffee of better quality when compared to the elaborated from fruits of Coffea canephora, considered inferior due to the most acidic flavor (PETTIGREW, 1999).

In Brazil, with regard to the utilized harvest method, the fruit of the coffee tree must be clean and separated. It may be processed integrally by dry processing or without husk and mucilage by wet processing, originating the de-hulled and de-pulped grains. (MATOS, et al., 2003).

The wet processing of the fruit produces a softer drink and after the harvest the removal of the epicarp is held by mechanical de-huller or a de-pulper. In the sequence, the operation called degumming takes place, in which the mesocarp (the mucilage adhered to the endocarp) is removed. The degumming operation consists in the immersion of the de-hulled fruits in water for a 24 hours period, after which they will be washed in current water, generating great amounts of residual waters (DIAS \& BARROS.,1993).

The generated fermented degumming water is rich in organic matter and due to its high pollutant capacity its disposal became undesirable, without treatment in water courses (ROLZ et al.,1982).

Selected strains of microorganisms may chemically decompose the polluent constituents present in the residues being considered as the more ecological treatment employed until the present moment (FURTADO, 1997).

Certain strains may degrade phenols, hydrocarbons and even chlorinated aromatic compounds. While some microorganisms are particularly efficient in decontaminate polluted soils, others are more utilized in industrial wastewater treatment. For example, Pseudomonas halodesnitrificans, in absence of oxygen transforms by reduction, 
nitrates in molecular nitrogen, inert gaseous element (DESPOLUIÇÃO..., 2000).

As stated by MACÊDO (2000) biodepollution may be defined as the incorporation of microorganisms to the wastewater treatment station, being considered a progress in biotechnology. When applied to liquid or solid organic residues, changes the physical-chemical properties, enhancing the degradation rates and making it suitable for disposal in water courses. The degradation rates may be evaluated by the Oxygen Biochemical Demand (OBD) and by Oxygen Chemical Demand (OCD). The OBD is a well utilized parameter and gives information about the concentration of oxygen necessary to biologically oxidize the organic material present in water (KAWAI, 1991; SPERLING, 1996). The OCD, is also being employed as it offers faster operations. The oxygen present in organic matter that can be oxidized, is measured by utilizing a oxidizing agent extremely acid (BRAILE \& CAVALCANTI,1979).

The aim of the present work was to isolate yeast strains capable of degrading the degumming water originated from the wet processing of coffee and to characterize the formed metabolites.

\section{MATERIAL AND METHODS}

This research was realized at Centro de Pesquisa e Processamento de Alimentos (CEPPA) and at Laboratório de Processos Biotecnológicos of Universidade Federal do Paraná, during the period of July 2001 to July 2003.

The coffee cherries samples of 2000/2001 crops and the degumming water were gently given by Instituto Agronômico do Paraná (IAPAR).

\subsection{ISOLATION AND SELECTION OF YEAST STRAINS}

The coffee cherries were selected and the envelope (husk, pulp and mucilage) manually separated from the grain. From each sample, $25 \mathrm{~g}$ of the envelope was weighed which was macerated in gral with the aid of a pistil. It was added to the macerate $100 \mathrm{~mL}$ of distilled water, which was filtered in volumetric flask and the volume was completed to 
$150 \mathrm{~mL}$. This solution was distributed in three Erlenmeyer flasks of $250 \mathrm{~mL}$ (50 mL/flask). The Erlenmeyer flasks were incubated in shaker for 3 days at $28^{\circ} \mathrm{C}$ and $120 \mathrm{rpm}$ (PAGNONCELLI, 2002).

\subsubsection{Culture media preparation}

For yeasts isolation, six different culture media were employed: yeast medium agar (YM), starch agar (AA), saccharose agar (ASC), potato dextrose agar (PDA) dichloran rose bengal chloramphenicol agar (DRBC) and coffee extract agar (AEC), as specified in Table1.

\section{TABLE 1 - CULTURE MEDIA COMPOSITIONS (YM, AA, ASC, PDA, DRBC AND AEC) UTILIZADED FOR YEASTS STRAINS ISOLATION}

\begin{tabular}{|c|c|c|c|c|c|c|}
\hline & \multicolumn{6}{|c|}{ Culture media } \\
\hline Composition & YM agar & AA & ASC & PDA & DRBC & AEC \\
\hline $\begin{array}{l}\text { - Bacteriological } \\
\text { agar }\end{array}$ & $20 \mathrm{~g}$ & $20 \mathrm{~g}$ & $20 \mathrm{~g}$ & $20 \mathrm{~g}$ & $20 \mathrm{~g}$ & $20 \mathrm{~g}$ \\
\hline - Distilled water & $\begin{array}{c}1000 \\
\mathrm{~mL}\end{array}$ & $1000 \mathrm{~mL}$ & $1000 \mathrm{~mL}$ & $1000 \mathrm{~mL}$ & $1000 \mathrm{~mL}$ & $1000 \mathrm{~mL}$ \\
\hline $\begin{array}{l}\text { - Macerated coffee } \\
\text { cherries }\end{array}$ & - & - & - & - & - & $500 \mathrm{~g}$ \\
\hline - Chloramphenicol & - & - & - & - & $0.1 \mathrm{~g}$ & - \\
\hline - Dextrose & $10 \mathrm{~g}$ & $10 \mathrm{~g}$ & $10 \mathrm{~g}$ & $20 \mathrm{~g}$ & $10 \mathrm{~g}$ & - \\
\hline - Dicloran & - & - & - & - & $0.002 \mathrm{~g}$ & - \\
\hline $\begin{array}{l}\text { - Dihidrogen sodium } \\
\text { phosphate }\end{array}$ & - & - & - & - & $1 \mathrm{~g}$ & - \\
\hline - Yeast extract & $3 \mathrm{~g}$ & $3 \mathrm{~g}$ & $3 \mathrm{~g}$ & - & - & - \\
\hline - Malt extract & $3 \mathrm{~g}$ & $3 \mathrm{~g}$ & $3 \mathrm{~g}$ & - & - & - \\
\hline - Potato infusion & - & - & - & $200 \mathrm{~g}$ & - & - \\
\hline $\begin{array}{l}\text { - Bacteriological } \\
\text { peptone }\end{array}$ & $5 \mathrm{~g}$ & $5 \mathrm{~g}$ & $5 \mathrm{~g}$ & - & $5 \mathrm{~g}$ & - \\
\hline - Rose bengal & - & - & - & - & $0.025 \mathrm{~g}$ & - \\
\hline - Magnesium sulfate & - & - & - & - & $0.5 \mathrm{~g}$ & - \\
\hline
\end{tabular}

Note: adjust $\mathrm{pH}$ to 4.5 .

$\mathrm{YM}=$ yeast medium, $\mathrm{AA}=$ starch agar, $\mathrm{ASC}=$ saccharose agar $\mathrm{PDA}=$ potato dextrose agar, $\mathrm{DRBC}=$ dichloran rose bengal chloramphenicol agar, $\mathrm{AEC}=$ coffee extract agar. 
The culture media were sterilized and distributed aseptically in Petry dishes $(20 \mathrm{~mL} /$ plate).

\subsubsection{Inoculation}

After three days of fermentation the Erlenmeyer flasks were removed from shaker and transferred to a sterile chamber. The inoculation was done in the agar surface from serial dilutions. In the surface of each plate $0,1 \mathrm{~mL}$ of each dilution was inoculated, being homogenized with the aid of a sterile Drigalski loop. The plates were inoculated with three replicates (PAGNONCELLI, 2002).

\subsubsection{Incubation}

The plates were incubated at $28^{\circ} \mathrm{C}$ for 5 days.

\subsubsection{Screening and colonies selection}

The colonies were selected by their morphological characteristics presented in each culture media. The criteria utilized were: aspect (creamy and wrinkled), color (very white, white, white yellowish, yellow, pink, media color), size ( $>2 \mathrm{~mm}$ or $<2 \mathrm{~mm}$ ) and edge (regular or irregular). The selected colonies were submitted to GRAM staining (PAGNONCELLI, 2002).

\subsubsection{Maintenance of selected strains}

The strains were inoculated in YM agar slants, which were incubated at $28^{\circ} \mathrm{C}$ for 48 hours and maintained at $4^{\circ} \mathrm{C}$ being re-inoculated every 3 months.

\subsubsection{Identification of the selected yeast strains}

The isolated strains were identified by the system API 20C AUX (BIOMÉRIEUX, 1993). This system allows the evaluation of 21 characteristics (20 biochemical and 1 morphological). This are 
separated in 7 groups of 3 and to each positive reaction is attributed a numerical value, composing a code of 7 digits. This code corresponds to species identification. The characteristics evaluated are the fermentation of the following components: glucose, glycerol, 2-ceto-dglucanate, arabinose, xylose, adonitol, xylitol, galactose, inositol, sorbitol, methyl-d-glucoside, n-acetyl-glucosamin, celobiose, lactose, maltose, saccharose, trealose, melezitose, rafinose and the presence of hifes.

2.2 INOCULATION OF THE YEASTS ISOLATED FROM COFFEE CHERRIES IN THE DEGUMMING WATER

\subsubsection{Characterization of degumming water}

The degumming water composition was defined from the analysis of $\mathrm{pH}$, humidity, ashes, lipids, proteins, carbohydrates, caloric value and total sugars realized following analytical methods of IAL (1985).

\subsubsection{Inoculum preparation}

The isolated yeast strains were inoculated in tubes containing $10 \mathrm{~mL}$ of $\mathrm{YM}$ broth and the tubes were incubated at $28^{\circ} \mathrm{C}$ for 48 hours.

\subsubsection{Degumming water preparation as fermentation substrate}

The degumming water was distributed in Erlenmeyer flasks with $250 \mathrm{~mL}$ capacity ( $50 \mathrm{~mL} /$ Erlenmeyer flask) and the flasks were sterilized at $121^{\circ} \mathrm{C} / 20$ minutes.

\subsubsection{Inoculation and Fermentation}

For each Erlenmeyer flask containing the sterile degumming water, $5 \mathrm{~mL}$ of every tube containing the 48 hour inoculum in YM broth was transferred. The Erlenmeyer flasks were incubated in shaker for 3 days at $28^{\circ} \mathrm{C}$ and $120 \mathrm{rpm}$. 


\subsection{EVALUATION OF THE DEGUMMING WATER DEGRADATION}

The degumming water degradation rates were evaluated by Oxygen Chemical and Biochemical Demands, before and after 48 hours of inoculation, by the method described in Standard Methods for Examination of Water and Wastewater (APHA, 1998).

\subsection{CHARACTERIZATION OF THE FORMED COMPOUNDS AFTER FERMENTATION BY THE YEAST STRAIN THAT SHOWED THE GREATEST DEGRADATION CAPACITY}

From the results obtained in the analysis of OBD and OCD, the yeast strain that showed the best degradation capacity of the degumming water was selected. The formed metabolites were characterized by gas chromatography (Chromatograph Varian, model CG3800 coupled to mass detector Varian, model Saturn 2000).

Aliquots of $50 \mathrm{~mL}$ were removed from degumming water samples without yeast and after $24 \mathrm{~h}$, $48 \mathrm{~h}$ e $72 \mathrm{~h}$ of incubation. Every aliquot was extracted twice with $100 \mathrm{~mL}$ diclhoromethane and hexane solution (1:1). The extracts were combined and passed through a filter containing anhydrous sodium sulfate. The solvents were put in a rotative evaporator (Quimis) and the resultant residue re-suspended and added of acetone to $5 \mathrm{~mL}$. The solutions obtained were analyzed by gas chromatography coupled to a mass spectrometer (GC/MS). The conditions of the GC/MS system operation are demonstrated in Table 2.

The compounds identification was realized by comparation with the spectrum stores in libraries of the chromatographic system utilizing as standards NIST and Saturn.

\section{RESULTS AND DISCUSSION}

\subsection{IDENTIFICATION OF THE COLONIES ISOLATED FROM COFFEE CHERRIES BY BIOCHEMICAL TESTS API 20CAUX}

The results obtained by the identification system API 20C aux showed 
that the isolated colonies from coffee cherries represented six distinct yeast species: Candida parapsilopsis, C.guilliermondii, C.lypolitica, C.tropicalis, Rhodorotula rubra e Kloeckera apiculata.

TABLE 2 - CONDITIONS OF ANALYSIS IN THE GC/MS SYSTEM

PARAMETERS

Injector temperature

Injection mode

Column initial temperature

Heating ramp

Final temperature

Trail gas flux $(\mathrm{He})$

Column

Interface temperature

Trap temperature

Manifold temperature

Ionization mode

\section{CONDITIONS}

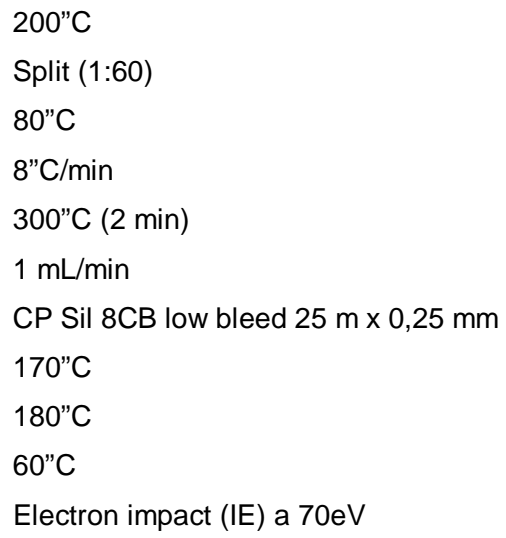

200"C

Split (1:60)

$80 " \mathrm{C}$

8 "C/min

$300 " \mathrm{C}(2 \mathrm{~min})$

$1 \mathrm{~mL} / \mathrm{min}$

CP Sil 8CB low bleed $25 \mathrm{~m} \times 0,25 \mathrm{~mm}$

$170 " \mathrm{C}$

$180 " \mathrm{C}$

$60 " \mathrm{C}$

Electron impact (IE) a 70eV

VAN PEE \& CASTELEIN (1971) isolated 8 yeast species, present even at the surface as in the mucilage of the cherries of Coffea canephora (robust) cultivated in Congo Republic. From those, three (Candida guilliermondii, Candida parapsilopsis e Candida tropicalis) coincided with the strains isolated in this experiment demonstrating that the distant cultivation regions presented similar microbiota.

\subsection{DEGUMMING WATER CHARACTERIZATION}

The results of the characterization of degumming water are demonstrated in Table 3. 
TABLE 3 - DEGUMMING WATER CHARACTERIZATION BY THE ANALYSIS OF $\mathrm{pH}$, PERCENTUAL COMPOSITION AND TOTAL SUGARS

\begin{tabular}{l|c}
\hline ANALYZED PARAMETER & RESULTS OBTAINED \\
\hline -pH & 4.12 \\
\hline -Humidity $(\mathrm{g} / 100 \mathrm{~mL}):$ & 97.24 \\
\hline -Ashes $(\mathrm{g} / 100 \mathrm{~mL}):$ & 0.29 \\
\hline -Lipids $(\mathrm{g} / 100 \mathrm{~mL}):$ & 0.10 \\
\hline -Proteins $(\mathrm{g} / 100 \mathrm{~mL}):$ & 0.34 \\
\hline -Carbohydrates $(\mathrm{g} / 100 \mathrm{~mL}):$ & 1.86 \\
\hline -Caloric value $(\mathrm{Kcal} / 100 \mathrm{~mL}):$ & 10.38 \\
\hline -Total sugars $(\mathrm{g} / 100 \mathrm{~mL})$ & $0.86(\mathrm{glucose})$ \\
\hline
\end{tabular}

The degumming water shows low $\mathrm{pH}$ value (below 4.5), which favors the preferential development of yeasts with utilization of the carbohydrates and total sugars as carbon source in the fermentation substrate.

\subsection{EVALUATION OF DEGUMMING WATER DEGRADATION}

The reduction percentiles of the OBD and OCD values of the degumming water obtained after 48 hours of inoculation compared to the initial values are demonstrated in Table 4.

\section{TABLE 4 - REDUCTION PERCENTILES OF OBD AND OCD OF DEGUMMING WATER}

\begin{tabular}{l|c|c}
\hline Microorganism & \% reduction OBD/48 hours & \% reduction OCD/48 hours \\
\hline Candida parapsilopsis & 50.14 & 29.81 \\
\hline Candida guilliermondii & 35.23 & 9.99 \\
\hline Candida lypolitica & 22.63 & 9.02 \\
\hline Rhodorotula rubra & 21.79 & 3.63 \\
\hline Kloeckera apiculata & 15.75 & - \\
\hline Candida tropicalis & 5.44 & - \\
\hline
\end{tabular}

Initial OCD: 35.294.11 mg O2/L. Initial OBD: 21.930 .12 mg O2/L. 
As stated by BAILLY et al. (1992) the degumming water, evaluated in wet processing plants situated in Mexico, presented essentially organic contamination (with high values of OBD and OCD). Values of OBD $19.000 \mathrm{mg} \mathrm{O} / \mathrm{L}$ and of OCD $34.000 \mathrm{mg} \mathrm{O2} / \mathrm{L}$ were found, showing that they are quite close to the ones obtained in the degumming water analyzed.

Although highly pollutant, the residual water shows good degradability (OCD/OBD between 1.5 to 2 ) which favors the treatment by biological means.

By comparing the degradation percentiles obtained it is observed that Candida parapsilopsis showed degradation percentiles very superior to the others, designating its depollutant potential.

ROLZ et al. (1982) isolated a strain of Penicillium crustosum capable of degrading chlorogenic acid (carbon source) and caffeine (nitrogen source) present in the residues of coffee processing (pulp, de-pulping and degumming water), making viable the use of this microorganisms as biodepollutants.

\subsection{CHARACTERIZATION OF THE COMPOUNDS SYNHETIZED BY THE STRAIN Candida parapsilopsis IN THE DEGUMMING WATER}

The comparison between the chromatograms of the various degumming water fractions (without yeast, $24 \mathrm{~h}$, $48 \mathrm{~h}$ e $72 \mathrm{~h}$ ) revealed the appearance of 3 new compounds in relation to the initial fraction. In the 48 hours fraction it was observed the appearance of compound 1, which is accentuated in the 72 hours fraction, in which it was also observed the synthesis of compounds 2 and 3 (Figure 1 ).

The identification of the formed compounds was realized through the comparison of their spectra with the ones stored in the libraries NIST and Saturn. The mass spectrum in relative percentage composition and the identidy suggested are presented in Table 5. 


\section{FIGURE 1 - CHROMATOGRAMS OF THE SAMPLE WITHOUT YEAST AND 72 HOURS SAMPLE}

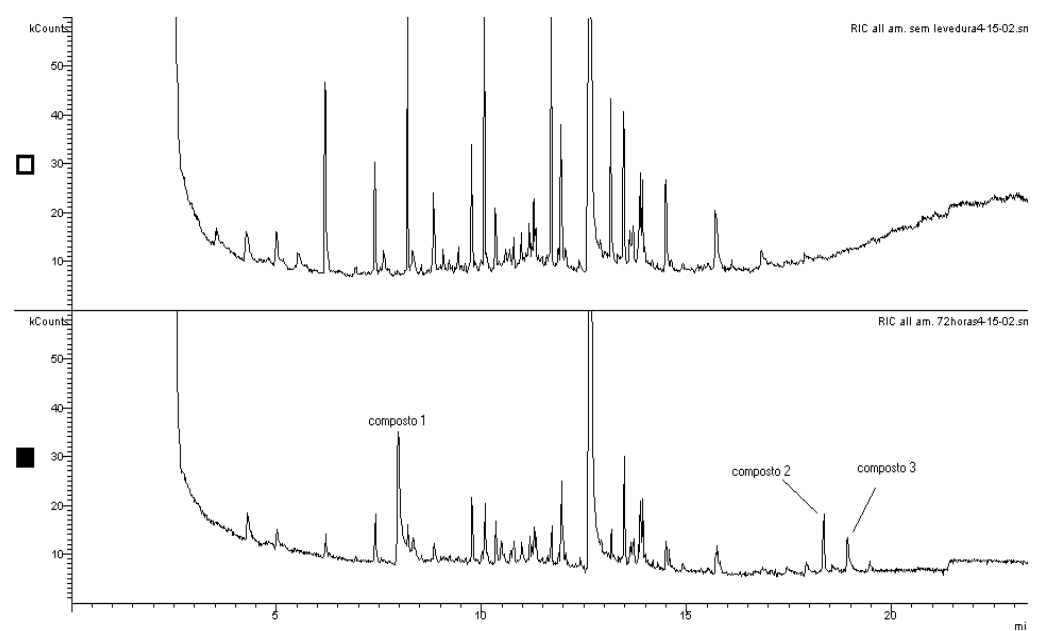

\section{TABLE 5 - MASS SPECTRUM AND SUGGESTED IDENTIFICATION}

\begin{tabular}{|c|c|c|c|}
\hline \multirow[t]{2}{*}{ Compound } & \multirow{2}{*}{$\begin{array}{c}\text { Mass spectrum } \\
\text { Relative quantity (\%) }\end{array}$} & \multicolumn{2}{|c|}{ Suggested Identification } \\
\hline & & NIST & Saturn \\
\hline Compound 1 & $\begin{array}{l}\text { 138(32); 108(10); 107(100); } \\
\text { 79(11); 78(11); 77(11). }\end{array}$ & $\begin{array}{l}\text { Benzeneethanol, 4- } \\
\text { hidroxy- } \\
\text { CAS N" 501-94-0 }\end{array}$ & $\begin{array}{l}\text { Benzeneethanol, 4- } \\
\text { hidroxy- } \\
\text { CAS N" 501-94-0 }\end{array}$ \\
\hline Compound 2 & $\begin{array}{l}386(17) ; 372(26) ; 371(100) ; \\
315(18) ; 119(7) ; 91(11)\end{array}$ & $\begin{array}{l}\text { 2,4- } \\
\text { Bis(dimethyilbenzyl)-6- } \\
\text { t-butylphenol } \\
\text { CAS N" -x- }\end{array}$ & $\begin{array}{l}\text { 2,4-Bis(dimethyilbenzyl)- } \\
\text { 6-t-butylphenol } \\
\text { CAS N" -x- }\end{array}$ \\
\hline Compound 3 & $\begin{array}{l}\text { 331(7); 330(28); 316(28); } \\
\begin{array}{l}315(100) ; \quad 237(13) ; \quad 119(5) ; \\
91(11) .\end{array}\end{array}$ & $\begin{array}{l}\text { Phenol, 2,4- bis (1- } \\
\text { methyl-1-phenylethyl)- } \\
\text { CAS N" 2772-45-4 }\end{array}$ & $\begin{array}{l}\text { Phenol, 2,4- bis (1- } \\
\text { methyl-1-phenylethyl)- } \\
\text { CAS N" 2772-45-4 }\end{array}$ \\
\hline
\end{tabular}


Both the libraries returned the same results for the compounds identity. The first one reveals the formation of a alcoholic compound characteristic of the primary metabolism of the yeasts. Compounds 2 and 3 are considered secondary metabolites of fermentation showing the utilization of alternative metabolic pathways by the yeast, this is because of the presence of small amounts of fermentable sugars in the substrate.

\title{
4 CONCLUSION
}

From the six yeast species (Candida tropicalis, C. lypolitica, C. guilliermondii, C. parapsilopsis, Kloeckera apiculata e Rhodotorula rubra), isolated from the coffee cherries, Candida parapsilopsis was the strain that revealed the best reduction percentile of OBD and OCD (respectively $50.14 \%$ e $29.81 \%$ ), degrading the degumming water and showing the viability of using this microorganisms as biological depollutants.

\section{RESUMO}

\begin{abstract}
DESENVOLVIMENTO DE BIOPROCESSO APLICADO AO TRATAMENTO DE ÁGUAS RESIDUAIS DO BENEFICIAMENTO ÚMIDO DO CAFÉ PELA INCORPORAÇÃO DE LINHAGEM SELECIONADA DE LEVEDURAS

O objetivo deste trabalho foi isolar cepas de leveduras capazes de degradar a água de degomagem do beneficiamento úmido do café, caracterizando os metabólitos formados. A bebida preparada a partir de grãos tratados por via úmida é considerada de melhor qualidade quando comparada à elaborada com grãos tratados por via seca. No entanto, o alto potencial poluente da água residual do beneficiamento representa sério problema para o ambiente. A água de degomagem apresenta essencialmente contaminação orgânica, com taxas de demanda bioquímica de oxigênio (DBO) e demanda química de oxigênio (DQO) superiores a 20.000 mgOz/L. Candida tropicalis, C. lypolitica, C. guilliermondii, C. parapsilopsis, Kloeckera apiculata e Rhodotorula rubra, isoladas de cerejas de café, foram inoculadas em frascos contendo água de degomagem e esses, submetidos à agitação constante(120 rpm) por 48 horas, a $28^{\circ} \mathrm{C}$. Candida parapsilopsis apresentou percentual de redução da taxa de DBO de $50,14 \%$ e de DQO de $29,81 \%$, evidenciando a viabilidade do uso desses microrganismos como biodespoluentes.
\end{abstract}

PALAVRAS-CHAVE: CAFÉ; ÁGUA DE DEGOMAGEM; LEVEDURAS 


\section{REFERENCES}

1 APHA. American Public Health Association. Standard methods for examination of water and wastewater. $20^{\text {th }}$ ed. Washington, DC,1998.

2 BAILLY, H.; SALLÉE, B.; GARCIA-GARCIA, S. Projecto de tratamiento de águas residuales de benefícios húmedos.1.Diagnóstico de la contaminación. Café Cacao Thé, v.36, n.2, p.129-136, avril-juin. 1992

3 BIOMÉRIEUX. Analytical profile index. $2^{\text {éme }}$ ed. Marcy-L'Étole, France, 1993 (Api 20C aux) (Ref.20290).

4 BRAILE, P.M.; CAVALCANTI, J.E.W.A. Manual de tratamento de águas residuárias industriais: São Paulo: CETESB, 1979. 764 p.

5 DEMARCHI, M. Café: aspectos econômicos. [Curitiba]: SEAB, Dep. de Economia Rural, dez. 2001.

6 DESPOLUIÇÃO: os microorganismos ganham terreno. França-Flesh Meio Ambiente, n. 9, p. 6-7, [2000].

7 DIAS, M.C.L.de L.; BARROS, A. do R. Avaliação de métodos para remoção da mucilagem de sementes de café (Coffea arabica L.). Revista Brasileira de Sementes, v.15, n.2, p.191-202, 1993.

8 FURTADO, M.R. Controle ambiental chega ao subsolo. Química e Derivados, v.32, n.354, p.8-19, out 1997.

9 IAL. Normas analíticas do Instituto Adolfo Lutz: métodos químicos e físicos para análise de alimentos. 3.ed. São Paulo, 1985.

10 KAWAI, H. Avaliação do desempenho de estações de tratamento de esgotos. São Paulo: CETESB, 1991. 38 p.

11 MACÊDO, J.AB. de Programa de bioaumentação (Bioaugmentation): uma tecnologia avançada para tratamento de efluentes. Revista Nacional da Carne, v.24, p-106-116, 2000.

12 MATOS, A.T. et al. Remoção de DBO e DQO em águas residuárias de lavagem. Disponível em: <www.coffeebreak.com.br/ocafezal.asp ?SE=8\&ID=203>. Acesso em 31/03/2003.

13 PAGNONCELLI, M.G.B. Estudo da biodiversidade de bactérias lácticas isoladas de frutos de café no Estado do Paraná: isolamento, identificação e avaliação de seu potencial nos processos de ensilagem da casca de café. Curitiba, 2002. 102 f. Dissertação (Mestrado em Tecnologia Química), Curso de Pós-Graduação em Tecnologia de Alimentos, Universidade Federal do Paraná. 
14 PETTIGREW, Jane. Café. São Paulo: Nobel, 1999. 96 p.

15 ROLZ, C. et al. Biotechnology in washed coffee processing. Process Biochemistry, v.17, n.2, p. 8-10, Mar./Apr.1982.

16 SPERLING, M. V. Introdução à qualidade das águas e ao tratamento de esgotos. Belo Horizonte: UFMG, 1996. 243 p.

17 VAN PEE, W.; CASTELEIN, J. The yeast flora of fermenting robusta coffee. East African Agricultural and Forestry Journal., v.36, p.308-310, Jan. 1971. 